\title{
ЭКСПЕРИМЕНТАЛЬНОЕ ОБОСНОВАНИЕ КРОВООСТАНАВЛИВАЮЩЕГО ЭФФЕКТА 3\% ГЕЛЯ КАРБОКСИМЕТИЛЦЕЛЛЮЛОЗЫ
}

\author{
(С Бежин А.И. ${ }^{1}$, Солдатова Д.С. ${ }^{1}$, Литвиненко И.В. ${ }^{1}$, Горпинич А.Б. ${ }^{2}$ \\ ${ }^{1}$ Кафедра оперативной хирургии и топографической анатомии им. профессора А. Д. Мясникова \\ Курского государственного медицинского университета, Курск; ${ }^{2}$ кафедра общей хирургии \\ и анестезиологии Орловского государственного университета имени И.С. Тургенева, Орел \\ E-mail: dascha22118@mail.ru
}

Статья посвящена доказательной базе наличия кровоостанавливающей активности 3\% геля карбоксиметилцеллюлозы. Механизм действия основан на взаимодействии коллоидов: поглощении гидрофильными группами карбоксиметилцеллюлозы жидкой части крови - плазмы, с одной стороны; с другой, гель представляет собой матрицу, которая задерживает форменные элементы крови, формируя решетку для образования тромбоцитарного сгустка. Это подтверждают полученные результаты экспериментов in vivo и in vitro: препарат укорачивал время свертываемости крови на $36 \%(109,15$ с.) при травме печени и на 27\% (89,85 с.) при травме селезенки (p<0,05); уменьшал величину кровопотери на 14\% (67 мг) при травме печени и на 16\% (65,8 мг) при травме селезенки (p<0,05). Это открывает новые горизонты применения данного импланта как препарата комбинированного действия, обладающего как гемостатическим, так и противоспаечным действием при паренхиматозных кровотечениях.

Ключевые слова: местные гемостатики, гемостаз, гель карбоксиметилцеллюлозы 3\%, мезогель, паренхиматозное кровотечение, комбинированные препараты.

\section{EXPERIMENTAL JUSTIFICATION OF THE HEMOSTATIC EFFECT OF CARBOXYMETHYLCELLULOSE 3\% GEL Bezhin A.I. ${ }^{l}$, Soldatova D.S. ${ }^{1}$, Lytvynenko I.V. ${ }^{1}$, Gorpinich A.B. ${ }^{2}$ \\ ${ }^{1}$ Department of Operative Surgery and Topographic Anatomy named after Professor A. D. Myasnikov of Kursk State Medical University, Kursk; \\ ${ }^{2}$ Department of General Surgery and Anesthesiology of I.S. Turgenev Orel State University, Orel}

The article is devoted to investigating the possible hemostatic activity of carboxymethylcellulose $3 \%$ gel. The mechanism of action is based on the interaction of colloids: the hydrophilic groups of carboxymethylcellulose absorb the liquid part of blood - plasma and, on the other hand, the gel is a matrix that retains the blood cells, forming a lattice for developing a platelet clot. This fact was confirmed by the results of experiments in vivo and in vitro: the drug reduced the clotting time by $36 \%$ $(109.15$ s.) in case of liver injury and by $27 \%(89.85$ s.) in case of spleen injury $(p<0.05)$; it reduced blood loss by $14 \%(67$ mg.) on the model of liver injury and $16 \%(65.8 \mathrm{mg})$ on the model of spleen injury $(\mathrm{p}<0.05)$. This opens up new horizons for using this implant in cases of parenchymal bleeding as a drug with combined action: it has both hemostatic and anti-adhesive effects.

Keywords: local haemostatics, hemostasis, carboxymethylcellulose 3\% gel, mesogel, parenchymal hemorrhage, combined drugs.

Актуальной проблемой современной хирургии являются разработка и изучение препаратов местного (аппликационного) действия при операциях на паренхиматозных органах. Это связано с высокой хирургической активностью и частотой патологии данных органов. Так, травма печени занимает $17-26 \%[4,14]$ от общего числа закрытых повреждениях брюшной полости, селезенки $15-20 \%$ [15]; органическая патология: наличие кистозных образований, желчнокаменная болезнь [5]; опухолевые процессы печени $[6,18]$. Все хирургические манипуляции на паренхиматозных органах являются весьма опасными, из-за развития кровотечения. Несмотря на внушительный арсенал методов гемостаза, все большее внимание и предпочтение хирурги отдают местным кровоостанавливающим препаратам: из-за прицельного действия, отсутствия множества побочных эф- фектов, простоты применения и, что немало важно, эффективности [11]. Однако с течением времени и научного прогресса требования к таким препаратам растут, и наличие однонаправленного действия уже не является достаточным. Именно поэтому настает время комбинированных препаратов, обладающих комплексом действий для решения сразу несколько задач. Так, при операциях на паренхиматозных органах мало просто достичь устойчивого гемостаза, необходимо предупредить развитие спаечного процесса в брюшной полости, после применения данных материалов. Гель карбоксиметилцеллюлозы 3\% давно зарекомендовал себя как эффективное противоспаечное средство $[1,2,3,7,8,9,10,11,16]$. Однако в литературе отсутствуют данные о кровоостанавливающих свойствах этого препарата, что значительно расширило бы границы его применения. 
Таким образом, целью нашего исследования явилось экспериментальное обоснование кровоостанавливающего эффекта 3\% геля карбоксиметилцеллюлозы.

\section{МАТЕРИАЛЫ И МЕТОДЫ ИССЛЕДОВАНИЯ}

Материалами для исследований были выбраны следующие средства: опытный образец - гель противоспаечный рассасывающийся «Мезогель» стандартной рецептуры $3 \%$ карбоксиметилцеллюлозы, производство ООО «Линтекс», г. СанктПетербург; сравнительные образцы - губка гемостатическая «КМЦ» (ООО «Линтекс», г. СанктПетербург) выбрана для сравнения твердой агрегатной формы действующего вещества; губка гемостатическая коллагеновая ООО «Белкозин» г. Луга, один из самых применяемых препаратов в Российской Федерации, и гемостатическая губка, зарубежного производства «Тахокомб» Австрия лидер на европейском рынке.

Исследование включало эксперименты in vitro и in vivo.

Обоснование кровоостанавливающего эффекта в эксперименте in vitro производили с помощью методики определения гематокрита и времени конца свертывания крови, с использованием нативной крови 70 здоровых доноров мужского пола, в возрасте от 18 до 20 лет.

С письменного согласия, соблюдая правила асептики и антисептики, донору пунктировали вену в локтевой области, после чего производили забор 3 мл крови. Затем к 1 мл донорской крови, помещенной в центрифужную пробирку с градуированной шкалой, добавляли 0,1 мл геля карбоксиметилцеллюлозы $3 \%$ из расчета $1 / 10$, в другой группе - такое же количество физиологического раствора. Контролем служила пробирка, содержащая только донорскую кровь. Вычисление гематокрита производили в трех группах: гематокрит чистой крови, крови донора и геля карбоксиметилцеллюлозы $3 \%$, крови донора с добавлением физиологического раствора. Все пробирки помещали в центрифугу на 30 минут при 3000 оборотов в минуту, после чего величину гематокрита определяли по градуированной шкале и выражали в процентах.

Для метода определения конца времени свертываемости в кювету элекрокоагулографа Н-334 добавляли 1 мл донорской крови, что служило группой контроля, и исследуемые вещества - гемостатическая губка «КМЦ» размером 1х1х1 мм в сравнительных группах. В третьем опыте добавляли гель карбоксиметилцеллюлозы $3 \%$ объемом 0,1 мл. Были взяты минимальные размеры исследуемых веществ, что бы исключить влияние на свертывание крови наличия инородных веществ большой площади, что само по себе способствует более высокой агрегации тромбоцитов на дополнительной поверхности. Затем проводили регистрацию электрокоагулограмм, рассчитывали время конца свертывания крови. Вычисляли:

1) начало свертывания $\mathrm{T} 1$ - от начала исследования до первого импульса с уменьшенной амплитудой по формуле:

$$
\mathrm{T} 1=\mathrm{To}+\mathrm{Taв},
$$

где То - время, прошедшее с момента взятия крови до начала записи; Тав - время от начала записи до первого импульса с уменьшенной амплитудой (до точки В рис. 1); Т1 - время от начала свертывания до появления первых нитей фибрина.

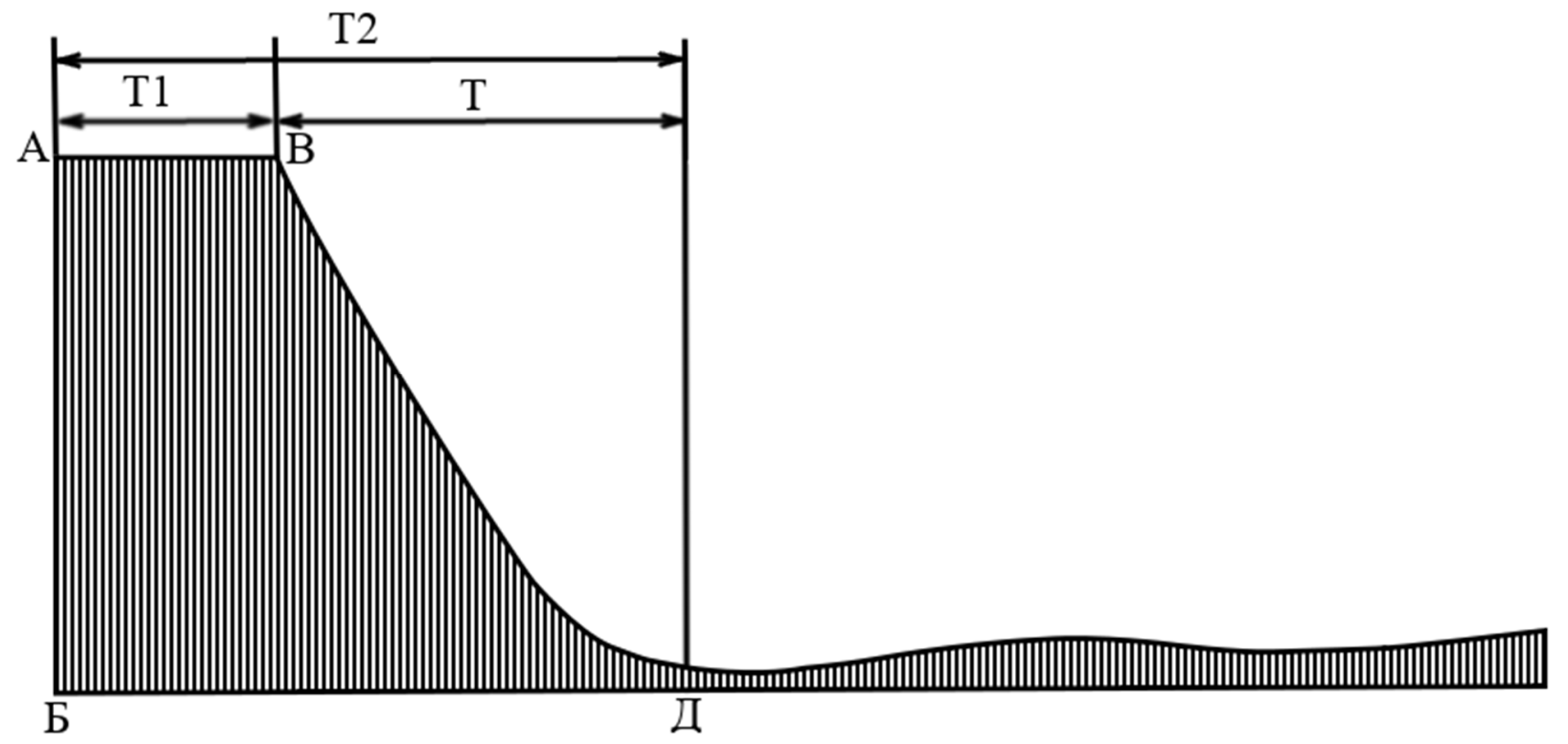

Рис. 1. Схема расчета времени начала и конца свертывания (объяснение в тексте). 
2) конец свертывания Т2 - от начала исследования до первого импульса с минимальной амплитудой по формуле:

$$
\text { Т2 = То + Тад, }
$$

где Тад - время от начала записи до первого импульса с минимальной амплитудой (до точки Д рис. 1); Т2 - время от начала исследования до первого импульса с минимальной амплитудой (расстояние между точками Б и Д рис.1).

Оценку гемостатических свойств материалов проводили по предложенному на кафедре оперативной хирургии и топографической анатомии коагуляционному индексу (КИ) (патент РФ № 2352940) начала свертывания (КИ Т1), который представляет отношение времени начала свертывания крови в опытном исследовании ко времени начала свертывания крови в контрольном опыте, и конца свертывания (КИ Т2) - отношение времени конца свертывания крови в опытном исследовании ко времени конца свертывания крови в контрольном опыте. Указанные индексы выражались в процентах и вычислялись по приведенным формулам.

$$
\text { КИ Т1 }=\frac{\mathrm{T} 1(\mathrm{M}) \times 100}{\mathrm{~T} 1(\kappa)}
$$

где Т1 (м) - время начала свертывания исследуемого материала в секундах, Т1 (к) - время начала свертывания в контроле в секундах.

$$
\text { КИ Т2 }=\frac{\mathrm{T} 2(\mathrm{M}) \times 100}{\mathrm{~T} 2(\kappa)}
$$

где Т2 (м) - время конца свертывания исследуемого материала в секундах, Т2 (к) - время конца свертывания в контроле в секундах.

Минимальные показатели КИ Т2 свидетельствуют о высокой гемостатической активности исследуемых материалов [12].

Все данные были обработаны статистически с вычислением средней величины, ошибки средней и достоверность результата, определяемого с помощью критерия Стьюдента [17].

Для подтверждения наличия кровоостанавливающего эффекта in vivo были выполнены методики определения времени остановки кровотечения и величины кровопотери.

В качестве лабораторных животных в эксперименте in vivo использовали крыс линии Вистар. Для стандартизации брали только особей мужского пола, массой 185-250 г, находящихся в стандартных условиях вивария (режим кормления и условия пребывания). Распределение животных было следующим: контрольная группа - без использования гемостатических средств; опытная группа с применением геля карбоксиметилцеллюлозы $3 \%$, в двух температурных режимах $\left(24^{\circ} \mathrm{C}\right.$ и $\left.36^{\circ} \mathrm{C}\right)$; и 4 группы сравнения - с использованием губки гемостатической «Белкозин» (са- мый распространенный и доступный по ценовой политике препарат в России), марлевой салфетки, которая является неотьемлемым материалом для остановки кровотечения во время любой открытой операции, «КМЦ» - губка гемостатическая из карбоксиметилцеллюлозы, использовали для сравнения кровоостанавливающих свойств действующего вещества в разных агрегационных состояниях; и зарубежного разрекламированного препарата - «Тахокомб». В каждой группе было по 20 животных. Всего использовали 140 крыс.

В остром опыте под масочным изофлюрановым наркозом крысам выполняли срединную лапаротомию. Под левую долю печени подкладывали марлевую салфетку с заведомо известной массой и отграничивали пропитывание последней жидкостью, продуцируемой брюшиной, с помощью полиэтиленовой пленки. Затем моделировали рану печени: отсекали край левой доли стандартным способом: для этого прикладывали трафарет в виде угольника, длина ребер последнего была равна $1 \mathrm{~cm}$, высота раны составляла 3 мм. После этого на кровоточащую область раны наносили исследуемые материалы: 1 мл геля карбоксиметилцеллюлозы 3\%, губку гемостатическую «Белкозин», «КМЦ», пластину «Тахокомб»

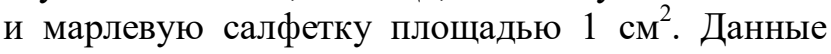
размеры рассчитаны в соответствии с площадью раневой поверхности. Группой контроля служила эта же методика без применения местных кровоостанавливающих средств. После моделирования раны включали секундомер и останавливали его после полного прекращения кровотечения: отсутствия выделения крови или истечения ее из под опытных образцов. Таким образом, регистрировали время остановки кровотечения. Величину кровопотери определяли как разницу в весе марлевой салфетки до эксперимента и после его окончания (пропитывания кровью) и вычисляли по формуле:

$$
\mathrm{m}=\mathrm{m} 2-\mathrm{m} 1,
$$

где $\mathrm{m} 2$ - масса салфетки после полного гемостаза (кровь, изливающаяся из раны, впитывалась в салфетку); $\mathrm{ml}$ - масса салфетки до эксперимента; $\mathrm{m}$ - величина кровопотери.

Полученные данные были обработаны статистически с вычислением средней величины, ошибки средней и достоверности различий (существенным считали, если последний показатель - б был меньше или равен 0,05). Достоверность различий оценивали методом вычисления доверительного интервала [17].

\section{РЕЗУЛЬТАТЫ ИССЛЕДОВАНИЯ И ИХ ОБСУЖДЕНИЕ}

Полученные результаты исследований определения величины гематокрита свидетельствуют 
о том, что гель карбоксиметилцеллюлозы 3\% обладает кровоостанавливающей активностью, достоверно уменьшая объем плазмы на 51\% (0,31 мл). Во всех случаях при добавлении препарата величина гематокрита увеличилась за счет абсорбции составляющим компонентом - карбоксиметилцеллюлозой жидкой части крови - плазмы. В 40\% (28 человек) случаев объем плазмы уменьшился на 0,3 мл; в 25\% (18 человек) - на 0,35 мл; в 13\% (9 человек) - на 0,4 мл и в $22 \%$ (15 человек) - на 0,25 мл, $(\mathrm{p}<0,05)$.

Распределение слоев после центрифугирования при добавлении геля карбоксиметилцеллюлозы $3 \%$ было иным, чем в контрольной пробирке (рис. 2А и 2Б).

В последней отмечалась классическая картина: нижний уровень составлял слой форменных элементов крови, верхний - плазма со стандартным соотношением 1 к 4. Тогда как в опытной пробирке нижний уровень также занимали форменные элементы крови, средней гель карбоксиметилцеллюлозы 3\% с адсорбированной частью плазмы, верхний слой - оставшаяся часть плазмы (распределение обусловлено удельным весом компонентов).

Для верификации данной методики выполняли добавление физиологического раствора к нативной крови, в объеме 0,1 мл. Это, напротив, привело к увеличению объема плазмы соответственно добавленной величине (на 17\%) во всех случаях (так как плотность физиологического раствора идентична плотности плазмы крови) $(\mathrm{p}<0,05)$.

Полученные нами данные нашли подтверждение при анализе коагулограмм. Нами было

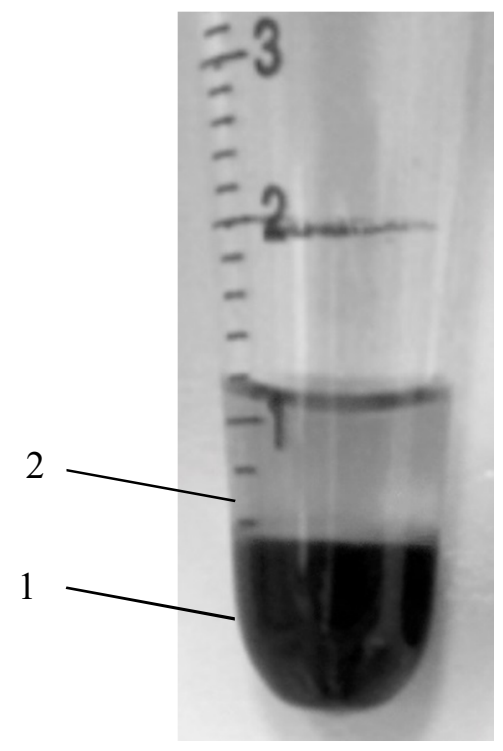

A. установлено, что при использовании исследуемых материалов (геля карбоксиметилцеллюлозы 3\% и губки гемостатической «КМЦ») укорачивалось время начала и конца свертывания крови во всех случаях.

Во всех случаях при применении препаратов по окончании опыта образовывался кровяной сгусток. Однако свертывающая активность в каждой группе была разной.

Максимальной кровоостанавливающей активностью обладает губка гемостатическая «КМЦ» $(\mathrm{p}<0,05)$, применение которой способствовало снижению времени свертывания крови относительно контрольных исследований: уменьшение КИ Т1 происходило на 50\% $(49,34 \pm 1,8)$ и КИ Т2 - на 53\% $(46,57 \pm 2,2)$. Кровоостанавливающая активность геля карбоксиметилцеллюлозы 3\% оказалась ниже: уменьшение КИ Т1 отмечалось на $27 \%(72,53 \pm 3,4)$ и КИ Т2 на $37 \% \quad(62,87 \pm 2,9) \quad(\mathrm{p}<0,05$ относительно контроля).

Таким образом, по выполнении эксперимента in vitro сделан вывод о том, что гель карбоксиметилцеллюлозы 3\% достоверно обладает кровоостанавливающими свойствами. Данный эффект основан на сорбции молекулами карбоксиметилцеллюлозы жидкой части крови - плазмы с одной стороны и формировании матрицы - решетки, задерживающей форменные элементы крови, в частности тромбоциты, создавая условия для формирования тромбоцитарного сгустка. Однако данные свойства оказались ниже, чем у «твердого» аналога «КМЦ», что связано с агрегационным состоянием последнего.

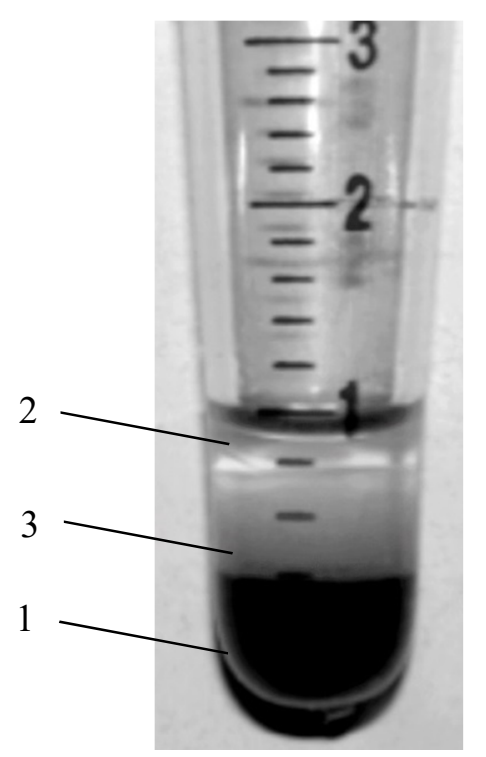

Б.

Рис. 2. Контрольная пробирка (А), содержащая кровь, и опытная пробирка (Б), содержащая кровь и гель карбоксиметилцеллюлозы $3 \%$.

Примечание: 1 - слой форменных элементов; 2 - плазма; 3 - гель карбоксиметилцеллюлозы 3\%. 
$\mathrm{C}$ целью дальнейшей верификации полученных данных выполнены серии экспериментов in vivo, в условия реального кровотечения.

Анализ полученных данных подтвердил ранее выявленные результаты: гель карбоксиметилцеллюлозы $3 \%$ обладает кровоостанавливающей активностью, укорачивая время остановки кровотечения на $36 \%(109,15$ с) при травме печени и на $27 \%(89,85$ с) при травме селезенки, относительно контроля и марлевой салфетки. Последний образец снижал показатель при травме печени лишь на $22 \%(66,83$ с) и на $24 \%(78,47$ с) при травме селезенки. Однако применение гемостатической губки «Белкозин» оказалось более эффективным в данном случае снижение показателя составило $55 \%$ (165 с) при травме печени и 52\% $(169,15$ с) при травме селезенки. Препараты «КМЦ» и «Тахокомб» оказались наиболее эффективными - укорочение времени кровотечения при травме печени составило $69 \%(208,93$ с) и $70 \%(212,04$ с) соответственно: при травме селезенки - 67\% $(218,97$ с) и $68 \%(222,06$ с) (рис. 3$)$.

При определении величины кровопотери в сравнительном аспекте выявлено, что гель карбоксиметилцелюллозы $3 \%$ и в данном случае обладает кровоостанавливающими свойствами, уменьшая данный показатель на 14\% (67 мг) при травме печени и на $16 \%(65,8$ мг) при травме селезенки $(\mathrm{p}<0,05)$. Но сорбционная способность марлевой салфетки оказалась выше, снижение показателей после применения данного образца составило $21 \%$ (103,3 мг) при травме печени и 17\% (69 мг) при травме селезенки. Сравнительные образцы также были более эффективными: снижение кровопотери при травме печени с использованием «КМЦ» произошло на $67 \%$ (279,1 мг); «Белкозина» - на 51\% (210,6 мг), «Тахокомба» - на 77\% (367,9 мг): при травме селезенки губка «КМЦ» снижала кровопотерю на $67 \%$ (317,2 мг), «Белкозин» - на 51\% (210,6 мг) и «Тахокомб» - на 77\% (317,2 мг) (рис. 4).

Для исключения кровоостанавливающего эффекта геля карбоксиметилцеллюлозы $3 \%$ только за счет охлаждающего вазоконстрикторного действия имплант был помещен на 30 минут в термостат при температуре $36^{\circ} \mathrm{C}$ (изменения химических и агрегационных свойств в данном температурном диапазоне не происходит согласно инструкции). Таким образом, выполнено исследование влияния температуры препарата на время остановки кровотечения и величину кровопотери. По результатам эксперимента выявлено, что препарат температуры тела $\left(36^{\circ} \mathrm{C}\right)$ не только сохранял кровоостанавливающее действие, но и вопреки ожидаемым результатам (увеличения кровопотери и длительности кровотечения за счет вазодилатации), оказался более эффективным, укорачивая время остановки кровотечения при травме печени на 38\% (114,69 с), при травме селезенки на $28 \%(90,07$ с). Этот эффект был подтвержден и в опыте по определению кровопотери: при травме печени снижение показателя происходило на $15 \%$ $(71,48$ мг) и при травме селезенки - на $17 \%$ $(70,49$ мг).

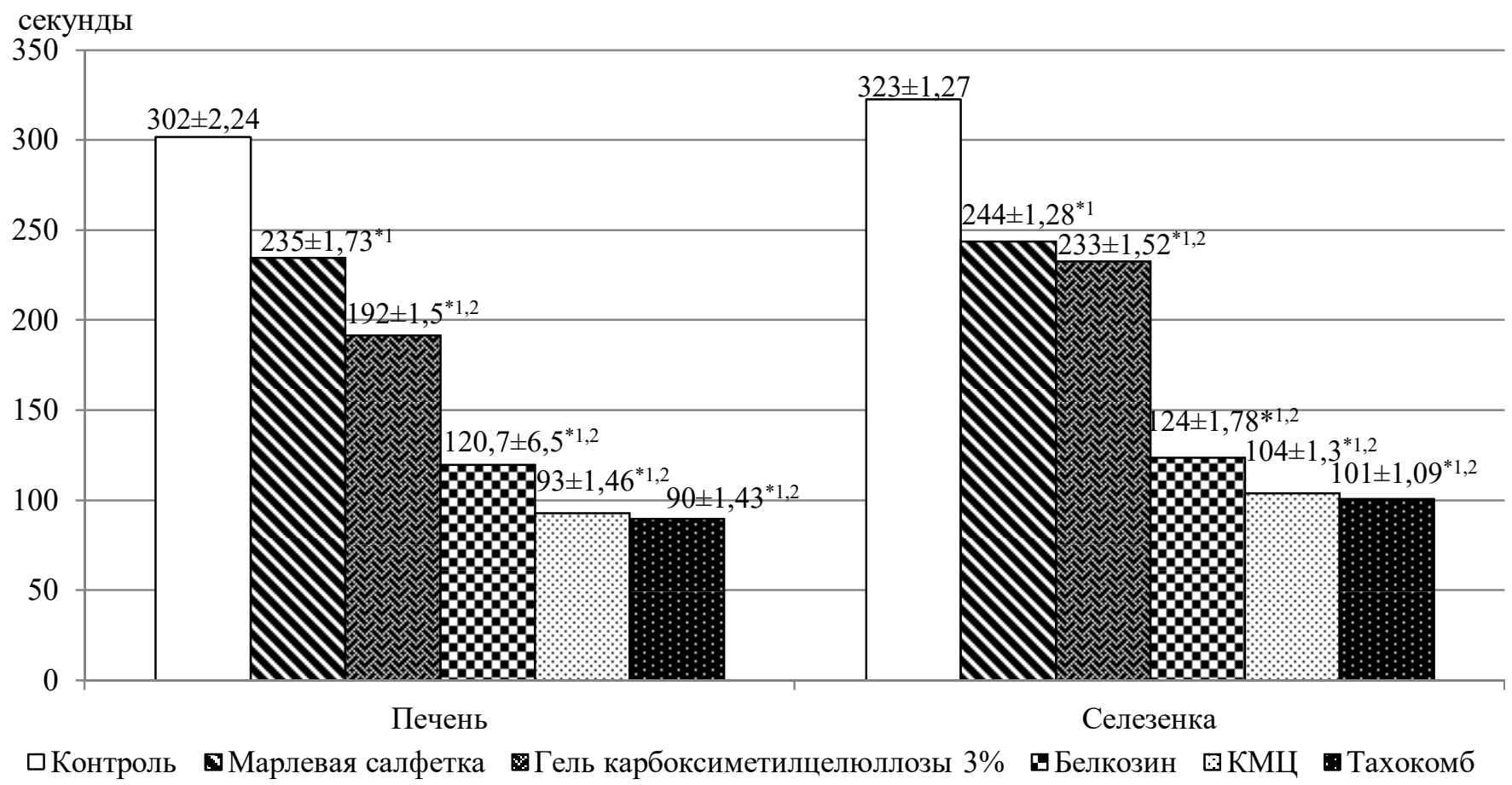

Рис. 3. Средние показатели времени остановки кровотечения в секундах в опытах in vivo $(\mathrm{M} \pm \mathrm{m})$.

Примечание: * - достоверные отличия относительно контрольных групп (цифра возле звездочки означает соответствующую группу сравнения: 1 - контроль, 2 - марлевая салфетка) с вероятностью 95\% при сравнении доверительных интервалов. 


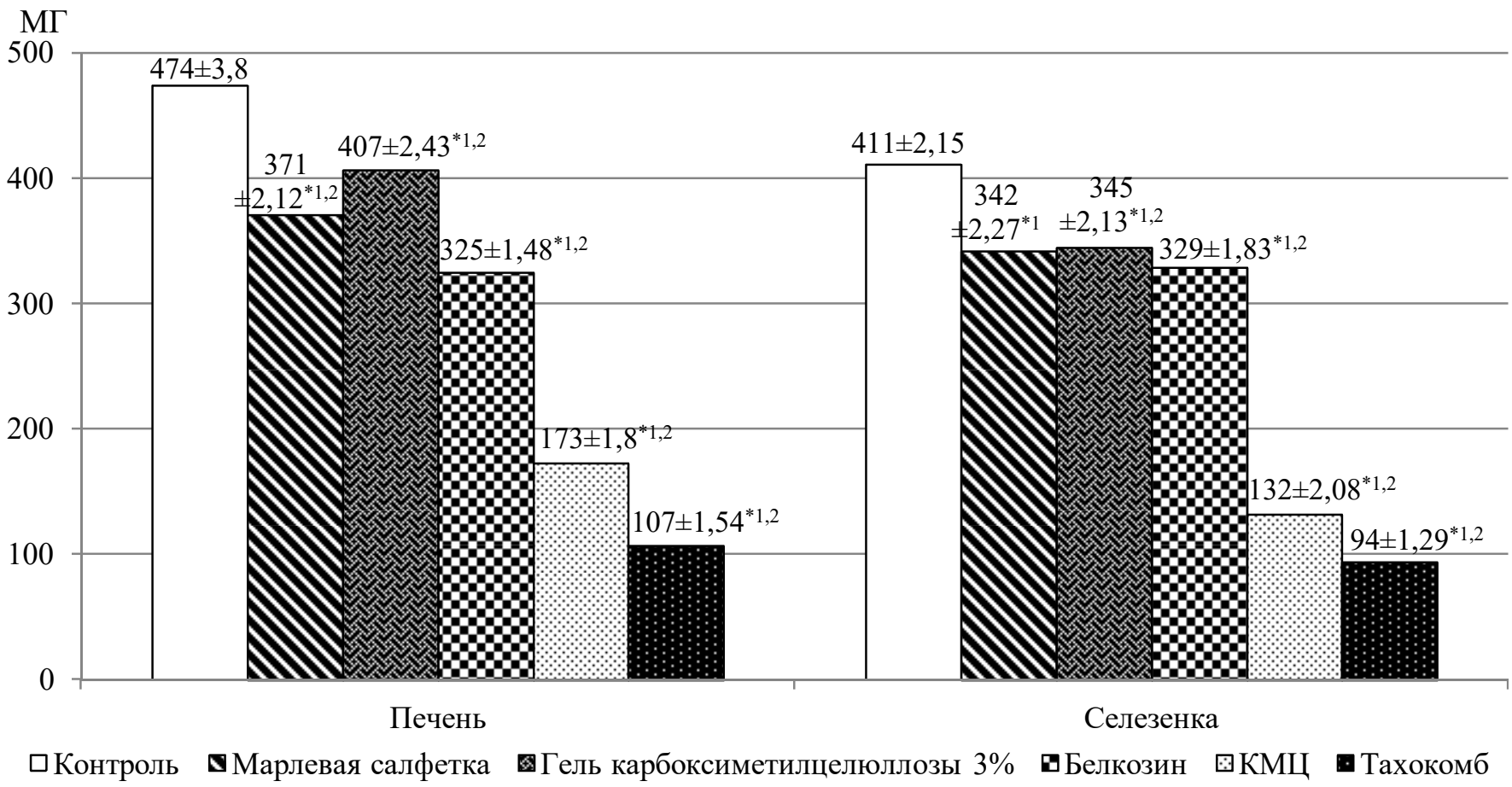

Рис. 4. Средние показатели величины кровопотери в миллиграммах в опытах in vivo $(\mathrm{M} \pm \mathrm{m})$.

Примечание: * - достоверные отличия относительно контрольных групп (цифра возле звездочки означает соответствующую группу сравнения: 1 - контроль, 2 - марлевая салфетка) с вероятностью 95\% при сравнении доверительных интервалов.

По результатам проделанной работы можно сделать следующие выводы.

Гель карбоксиметилцеллюлозы $3 \%$ достоверно обладает кровоостанавливающими свойствами, подтвержденными как в экспериментах in vitro, уменьшая объем плазмы на $51 \%(0,31$ мл, $\mathrm{p}<0,05)$, КИ Т1 на $25,66 \%(74,34 \pm 5,8)$, КИ Т2 на $32,04 \%(67,96 \pm 11,8)(\mathrm{p}<0,05)$, так и in vivo, укорачивая время остановки кровотечения на $36 \%$ $(109,15$ с) при травме печени и на $27 \%(89,85$ с) при травме селезенки $(\mathrm{p}<0,05)$; уменьшая величину кровопотери на 14\% (67 мг) при травме печени и на $16 \%$ (65,8 мг) при травме селезенки $(\mathrm{p}<0,05)$, по сравнению с контролем и являясь более эффективным гемостатическим агентом, чем марлевая салфетка. Однако гемостатические губки «Белкозин», «КМЦ» и «Тахокомб» оказались эффективнее во всех случаях: укорочение времени остановки кровотечения составило при травме печени соответственно: $55 \%$ (165 с), 69\% (208,93 с) и 70\% $(212,04$ c): при травме селезенки - 52\% (169,15 c), $67 \%(218,97$ с) и $68 \%(222,06$ с $)$.

Механизм действия основан на взаимодействии коллоидов: поглощения гидрофильными группами карбоксиметилцеллюлозы жидкой части крови - плазмы, с одной стороны; с другой гель представляет собой матрицу, которая задерживает форменные элементы крови, формируя решетку для образования тромбоцитарного сгустка.

Кровоостанавливающий эффект геля карбоксиметилцеллюлозы 3\% достоверно (относительно контроля) не связан с его охлаждающим действием на рану: препарат при $36^{\circ} \mathrm{C}$ укорачивал время остановки кровотечения при травме печени на $38 \%(114,69$ c), при травме селезенки - на 28\% $(90,07$ c), а также уменьшал величину кровопотери при травме печени на $15 \%$ (71,48 мг) и при травме селезенки на 17\% (70,49 мг).

\section{КОНФЛИКТ ИНТЕРЕСОВ}

Авторы декларируют отсутствие явных и потенциальных конфликтов интересов, связанных с публикацией настоящей статьи.

\section{ЛИТЕРАТУРА / REFERENCES}

1. Акрамов Э. Х., Ручкина К. В. Профилактика ранней острой кишечной непроходимости при деструктивных формах червеобразного отростка // Journal of Siberian Medical Sciences. - 2014. - № 2. C. 40-47. [Akramov E.H., Ruchkina K.V. Prophylaxis of the early acute intestinal obstruction at destructive forms of vermicular appendix. Journal of Siberian Medical Sciences. 2014; (2): 40-47 (in Russ.)].

2. Алмабаев Ы.А., Фахрадиев И.Р., Асанова Б.М. Биоэлектрическая стимуляция мышц передней брюшной стенки в профилактики спаечной болезни в эксперименте // Вестник Казахского Национального медицинского университета. - 2015. - № 3. C. 31-33. [Almabaev Y.A., Fahrad I.R, Asanov B.M. Bioelectric muscle stimulation of the anterior abdominal wall to prevent disease in the experiment. Vestnik Kazakhskogo Natsional'nogo meditsinskogo universiteta. 2015; (3): 31-33 (in Russ.)]. 
3. Атькова Е.Л., Роот А.О. Медикаментозные методы профилактики заращения соустья после эндоназальной дакриоцисториностомии // Вестник офтальмологии. - 2015. - Т. 131, № 5. - С. 68-73. DOI: 10.17116/oftalma2015131568-73. [At'kova E.L., Root A.O. Therapeutic methods of scar prevention at the site of endonasal dacryocystorhinostomy. Vestnik oftal'mologii. 2015; 131(5): 68-73 (in Russ.)].

4. Бородин О.Ю., Семичев Е.В., Байков А.Н., Бушланов П.С., Геренг Е.А., Кошевеи Е.С., Алейник А.Н. Экспериментально-лучевое исследование селезенки после резекции и гемостаза «неравновесной плазмой» // Сибирский научный медицинский журнал. - 2015. - Т. 35, № 3. - C. 9-13. [Borodin O.Yu., Semichev E.V., Baykov A.N., Bushlanov P.S., Gereng E.A., Koshevets E.S., Aleynik A.N. Experimental radiological investigation of spleen after resection and hemostasis by "non-equilibrium" plasma. Sibirskiy nauchnyy meditsinskiy zhurnal. 2015; 35(3): 9-13 (in Russ.)].

5. Глушков Н.И., Скородумов А.В., Сафин М.Г., Андрусенко А.В., Кветный М.Б., Периев А.В., Аминов Д.Х. Опыт малоинвазивного хирургического лечения желчнокаменной болезни // Вестник Северо-Западного государственного медицинского университета им. И.И. Мечникова. - 2016. - Т. 8, № 1. - C. 92-93. [Glushkov N.I., Skorodumov A.V., Safin M.G., Andrusenko A.V., Kvetnyi M.B., Pertsev A.V., Aminov D.Kh. Experience of minimally invasive surgical treatment of gallstone disease. Vestnik Severo-Zapadnogo gosudarstvennogo meditsinskogo universiteta im. I.I. Mechnikova. 2016; 8(1): 92-93 (in Russ.)].

6. Горчаков С.В., Правосудов И.В., Васильев С.В., Олейник В.В., Оношко М.В., Попов Д.Е. Мультидисциплинарный подход в лечении больных колоректальным раком с метастазами в печень - взгляд онколога сегодня // Поволжский онкологический вестник. - 2015. - № 4. - C. 70-78. [Gorchakov S.V., Pravosudov L.V., Vasilev S.V., Oleynik V.V., Onoshko M.V., Popov D.E. A multidisciplinary approach in the treatment of patients with colorectal cancer with liver metastases - opinion oncologist today. Povolzhskiy onkologicheskiy vestnik. 2015; (4): 70-78 (in Russ.)].

7. Гуменюк С.Е., Григорьев А.Г., Губиш А.В., Батчаева Р.А., Сторожук П.Г. Фармакологическая коррекция формирования соединительной ткани при аллопластике в эксперименте // Кубанский научный медицинский вестник. - 2015. - Т. 154, № 5. C. 47-51. [Gumenyuk S.E., Grigoriev A.G., Gubish A.V., Batchaeva R.A., Storozhuk P.G. Pharmacological correction of formation of connective tissue with mesh hernia repair in experiment. Kubanskiy nauchnyy meditsinskiy vestnik. 2015; 154(5): 47-51 (in Russ.)].

8. Дьяконова Е.Ю., Поддубный И.В., Бекин А.С. Спаечная кишечная непроходимость как одна из причин неотложных состояний у детей // Педиатрическая фармакология. - 2015. - Т. 12, № 3. C. 315-319. - DOI: 10.15690/pf.v12i3.1357. [Dyakonova E.Y., Poddubnyi I.V., Bekin A.S. Adhesive intestinal obstruction as one of the causes of emergency conditiond in children. Pediatricheskaya farmakologiya. 2015; 12(3): 315-319 (in Russ.)].

9. Кира Е.Ф., Левчук А.Л., Вязьмина К.Ю. Применение противоспаечных барьеров при миомэктомии у женщин репродуктивного возраста. // Вестник Национального медико-хирургического центра им. Н.И. Пирогова. - 2009. - Т. 4, № 2. - С. 50-52. [Kira E.F., Levchuk A.L., Vyazmina K.Ya. Application of anti-commissural barriers during myomectomy in females of reproductive age. Vestnik Natsional'nogo mediko-khirurgicheskogo tsentra im. N.I. Pirogova. 2009; 4(2): 50-52 (in Russ.)].

10. Кондратович Л.М. Основы понимания формирования спаечного процесса в брюшной полости. Интраоперационная профилактика противоспаечными барьерными препаратами (обзор литературы) // Вестник новых медицинских технологий. 2014. - T. 21, № 3. - C. 169-173. - DOI: 10.12737/5929. [Kondratovich L.M. The basics for comprehension of adhesive process formation in abdominal cavity. perioperative prevention by means of anti-adhesive drugs (review of literature). Vestnik novykh meditsinskikh tekhnologiy. 2014; 21(3): 169-173 (in Russ.)].

11. Липатов В.А., Ершов М.П., Сотников К.А., Ушанов А.А., Новикова Н.В., Константинова Ю.Е. Современные тенденции применения локальных аппликационных кровоостанавливающих средств // Научный электронный журнал "INNOVA”. - 2016. - T. 3, № 2. - C. 64-69. - DOI: 10.21626/innova/2016.2/07. [Lipatov V.A., Ershov M.P., Sotnikov K.A., Ushanov A.A., Novikova N.V., Konstantinova Yu.E. The modern trends of using local applicational blood reestablishing instruments of surgery of abdominal organs. Nauchnyy elektronnyy zhurnal "INNOVA". 2016; 3(2): 64-69 (in Russ.)].

12. Пат. 2352940 РФ, G01N33/49. Способ сравнительной оценки тромборезистентных свойств хирургических шовных материалов / А.А. Нетяга, А.Н. Майстренко, А.И. Бежин, В.А. Липатов, Г.М. Чижиков, В.С. Белоус, М.С. Гомон, Е.А. Бобровская (Россия). - № 2007123839/15; Заявлено 25.06. 2007; Опубл. 20.04. 2009, Бюл. № 11. [Patent No. 2352940 of the Russian Federation, G01N33/49. Method for comparative assessment of thromboresistant properties of surgical suture materials / A.A. Netyaga, A.N. Maystrenko, A.I. Bezhin, V.A. Lipatov, G.M. Chizhikov, V.S. Belous, M.S. Gomon, E.A. Bobrovskaya (Russia). No. 2007123839/15; Stated 25.06. 2007; Publ. 20.04. 2009, Byul. № 11 (in Russ.)].

13. Самариев В.А., Кузнеияова М.В., Гаврилов В.А., Кузнецова М.П., Париаков А.А. Противоспаечные барьеры в абдоминальной хирургии: современное состояние проблемы // Пермский медицинский журнал. - 2017. - Т. 34, № 2. - C. 87-93. [Samartsev V.A., Kuznetsova M.V., Gavrilov V.A., Kuznetsova M.P., Parshakov A.A Anticommissural barriers in abdominal surgery: up-to-date state of problem. Permskiy meditsinskiy zhurnal. 2017; 34(2): 87-93 (in Russ.)]. 
14. Семичев Е.В., Байков А.Н., Шевцова Н.М., Бушланов П.С., Геренг Е.А., Алейник А.Н. Морфофункциональные изменения селезенки после гемостаза неравновесной плазмой // Вестник Российской академии медицинских наук. - 2015. - Т. 70, № 5. - $\quad$ C. 592-598. $\quad-\quad$ DOI: 10.15690/vramn.v70.i5.1447. [Semichev E.V., Baikov A.N., Shevtsova N.M., Bushlanov P.S., Gereng E.A., Aleinik A.N. Morphofunctional changes of spleen after hemostasis by nonequilibrium plasma. Vestnik Rossiyskoy akademii meditsinskikh nauk. 2015; 70(5): 592-598 (in Russ.)].

15. Спиридонов А.А. Опыт применения отечественного гемостатического препарата при травме печени у детей // Практическая медицина. - 2017. - Т. 105, № 4. - C. 78-80. [Spiridonov A.A. Using a hemostatic medication of Russian production for liver trauma in children. Prakticheskaya meditsina. 2017; 105(4): 78-80 (in Russ.)].

16. Суковатых Б.С., Мясников А.Д., Бежин А.И., Лазаренко В.А., Липатов В.А., Дубонос А.А., Жуковский В.А., Вербицкий Д.А. Эффективность антиспаечного средства с барьерным действием «Мезогель» после рассечения спаек у пациентов с острой спаечной кишечной непроходимостью. // Вестник хирургии им. И.И. Грекова. - 2008. - Т. 5, № 167. C. 29-32. [Sukovatykh B.S., Myasnikov A.D.,
Bezhin A.I., Lazarenko V.A., Lipatov V.A., Dubonos A.A., Zhukovsky V.A., Verbitsky D.A. The efficiency of antiadhesive means with "Mezogel" having a barrier effect after dissection of the adhesions in patients with acute adhesive intestinal obstruction. Vestnik khirurgii im. I.I. Grekova. 2008; 5(167): 29-32 (in Russ.)].

17. Федеральная служба государственной статистики [Электронный ресурс]. - Режим доступа: http://www.gks.ru/, свободный (21.11.2018). [Federal State Statistics Service [Electronic resource]. - Access mode: http://www.gks.ru/, free (11/21/2018) (in Russ.)].

18. Шаврина Ю.А. Клинический случай лечения пациента с метастатическими неоперабельными опухолями печени с использованием радиочастотной абляции в сочетании с регионарной химиотерапией и химиоэмболизацией // Казанский медицинский журнал. - 2017. - Т. 98, № 3. - С. 446-448. DOI: 10.17750/KMJ2017-446. [Shavrina Yu.A. A clinical case of the treatment of a patient with metastatic inoperable liver cancers with the use of radiofrequency ablation combined with regional chemotherapy and chemoembolization. Kazanskiy meditsinskiy zhurnal. 2017; 98(3): 446-448. - DOI: 10.17750/KMJ2017-446 (in Russ.)]. 